DOI 10.34185/1562-9945-2-133-2021-14

УДК 004.021

Н.І. Глоба, I.С. Дмитрієва

\title{
РОЗРОБКА АЛГОРИТМУ ДЛЯ ПОБУДОВИ ПРОТОТИПУ ЕКСПЕРТНОЇ СИСТЕМИ ДІАГНОСТИКИ АВАРІЙНИХ СИТУАЦІЙ МЕРЕЖІ
}

Анотація. Сучасні електроенергетичні системи відносяться до класу великих людиномашинних систем кібернетичного типу, тому розробка експертної системи діагностики аварійних ситуацій є актуальною.

В роботі було розроблено модифікований алгоритм Дейкстри. Мета модифікації полягає в підвищенні ефективності запропонованого рішення, можливість роботи в зваженому графі і виключення помилок під час пошуку альтернативного шляху.

Ключові слова: експертна система, модифікований алгоритм, граф станів, електроенергетичні системи.

Складно уявити сучасний світ без електрики. Електрика стала невід'ємною частиною не тільки нашого життя, але й усіх виробничих процесів. Очевидно, що відсутність електроенергії може стати великою проблемою на підприємствах, що спричинить за собою фінансові втрати або аварійні випадки. Головне призначення електроенергетичних систем полягає у забезпеченні надійного постачання споживачів електричною енергією нормованої якості та у необхідних обсягах за умови мінімально можливих витрат.

Сучасні електроенергетичні системи відносяться до класу великих людино-машинних систем кібернетичного типу, оскільки характеризуються великою кількістю регульованих параметрів. Це означає, що задачі управління енергосистемами є нетривіальними і у більшості практичних випадків визначити оптимальний розв'язок таких задач неможливо. В умовах оперативного управління режимами енергосистем це пов'язано із жорстким обмеженням часу для прийняття рішення, а під час прогнозування перспективних режимів та проектування розвитку енергосистем - із невизначеністю та неоднозначністю вихідної інформації, наприклад, даних про перспективні навантаження енергосистеми [1].

Використовуючи експертну систему (ЕC), можна зменшити кількість інформації, яку потрібно враховувати диспетчеру і прискорити процес прийнят-

(C) Глоба Н.I., Дмитрієва I.C., 2021

128

ISSN 1562-9945 (Print)

ISSN 2707-7977 (Online) 


\section{«Системні технології» 2 (133) 2021 «System technologies»}

тя рішення. Також правильно побудована експертна система дозволить зменшити кількість потенційних помилок у прийнятих рішеннях.

В основі експертної системи лежить база знань про конкретну предметну область, яка повинна накопичуватися в результаті побудови та експлуатації ЕС. Інформація не завжди може бути подана точно, існує так звана «нечітка інформація» або «нечіткі» знання, правила обробки та подання якої базуються на логіці. Коли виникає ситуація, така, що для прийняття рішення або подання інформації не вистачає обсягу або повністю відсутня необхідна інформація, раціональне рішення може бути прийнято завдяки накопиченим знанням, в цьому i полягає головна перевага ймовірнісного над логічним. Це можливо завдяки накопиченню знань в базі даних, в результаті роботи експертної системи, після чого експертна система, базуючись на отриманих раніше знаннях, буде приймати рішення, грунтуючись на найбільш відповідній ймовірності так званій суб'єктивній довірі [2].

Розподілена електрична мережа за своєю структурою нагадує граф. Прикладом завдання, яке необхідно розв'язати за допомогою автоматизованої системи, може бути вибір маршруту перепідключення електромережі для відновлення роботи системи.

На наш погляд, більш ефективним для даної задачі буде використання алгоритм обходу графа. Існує безліч алгоритмів обходів графа: пошук в глибину, пошук в ширину, топологічне сортування і так далі. Однак, така велика кількість алгоритмів не завжди відповідає необхідним вимогам. Наприклад, більшість алгоритмів проходять тільки по вузлах, які проходять по найкоротшому шляху. Деякі алгоритми, навпаки, роблять надмірно багато заходів у вузли, щоб забезпечити входження у кожен вузол, працюють на неорієнтованому графі i, більш того, більшість алгоритмів мають дуже велику обчислювальну складність, оскільки прораховують всі можливі маршрути до кожного з вузлів, що в промислових масштабах впливає на час усунення аварії. Одним 3 таких є алгоритм Дейкстри.

Алгоритм Дейкстри - знаходить найкоротшу відстань від однієї з вершин графа до всіх інших. Працює тільки для графів без ребер негативної ваги.

Робота цього алгоритму виглядає наступним чином:

1) Створюється набір (найкоротший набір дерев шляху), який відстежує вершини, включені до дерева найкоротшого шляху. Спочатку цей набір порожній. 
«Системні технології» 2 (133) 2021 «System technologies»

2) Призначаються значення відстаней всім вершинам вхідного графіку. Спочатку всі значення відстаней беруться як нескінчені. Призначається значення відстані як 0 для вихідної вершини, щоб вона була вибрана першою.

3) Доки набор не включає всі вершини

3.1) Обирається вершина $\mathrm{u}$, якої немає в наборі і має мінімальне значення відстані.

3.2) Вершина и включається до набору.

3.3) Оновлюється значення відстаней до всіх сусідніх вершин вершини u [3].
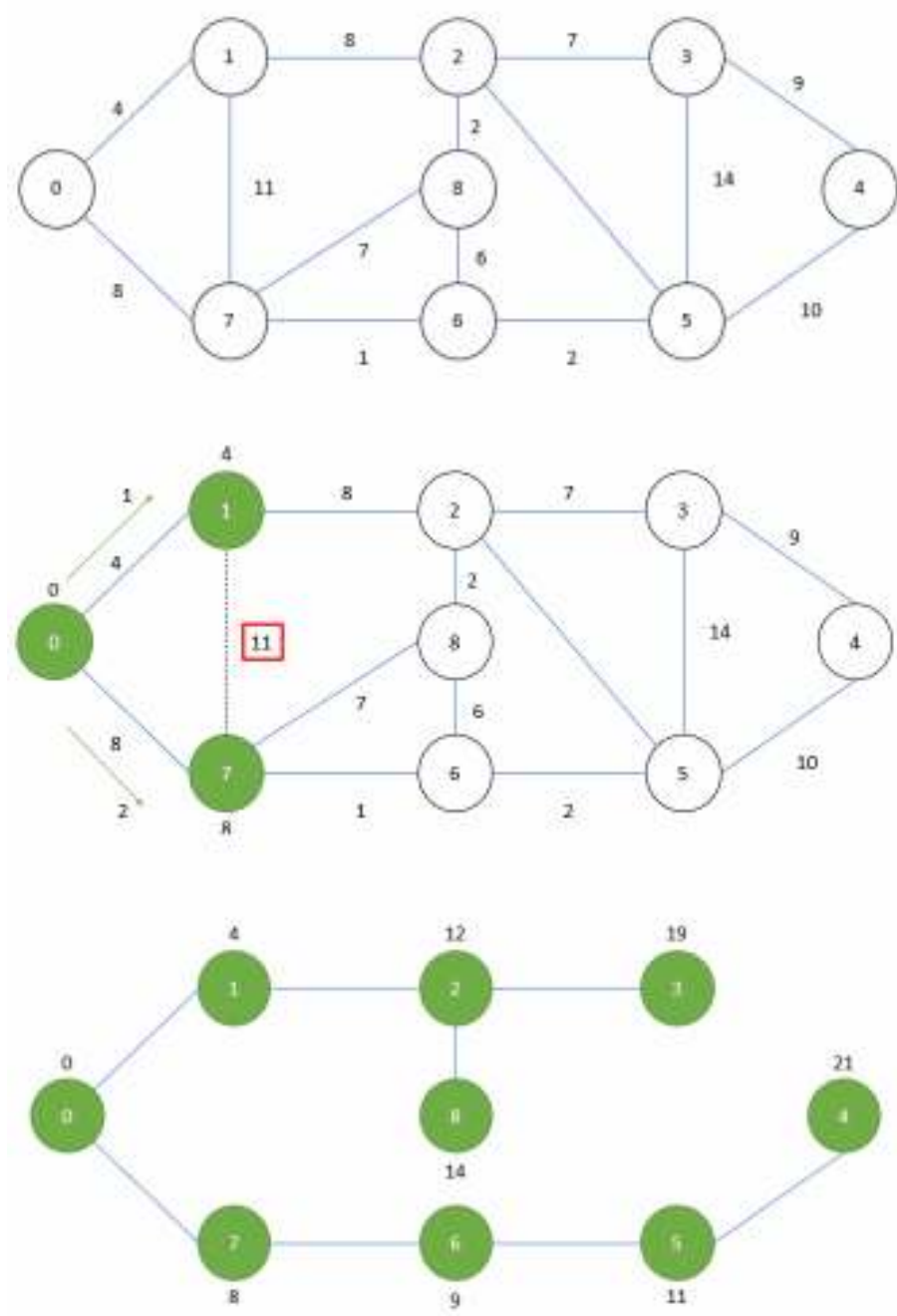

Рисунок 1 - Робота алгоритму Дейкстри

Алгоритм являє собою рішення задачі в загальному вигляді, яке не завжди буде актуальним для конкретного випадку. В рамках даної роботи було розроблено модифікованій алгоритм Дейкстри. 


\section{«Системні технологіï» 2 (133) 2021 «System technologies»}

Мета модифікації полягає в підвищенні ефективності запропонованого рішення, можливість роботи в зваженому графі і виключення помилок під час пошуку альтернативного шляху. Цей результат досягається шляхом запам'ятовування всіх зв'язкових вузлів і прорахунку мінімальних маршрутів до всіх вершин, з урахуванням ліній, що знаходяться в стані аварії.

Робота цього алгоритму виглядає наступним чином:

Кожне ребро має: id, вагу - протяжність лінії електропередачі, пов'язані вузли, а також статус (працює, резерв, аварія). Кожен вузол має: власне id, id початкового вузла графа при розрахунку маршруту, вагу мінімального маршруту, а також статус (працює, резерв, аварія).

1) При виникненні аварії, ребро а також всі вузли, які не мають маршруту з активних ребер - переходить у статус аварія.

2) Вага кожного вузла записується в масив, після чого встановлюється як нескінчена. Скидається id початкового вузла графа при розрахунку маршруту.

3) Для активних ребер - починаючи з початкового вузла, визначаємо зв'язані з ним вузли. Якщо пов'язаний вузол має розрахункову вагу меншу, ніж розрахункова вага поточного вузла з додаванням ваги зв'язуючого ребра, то для пов'язаного вузла встановлюємо розрахункову вагу, яка дорівнює розрахунковій вазі поточного вузла з додаванням ваги зв'язуючого ребра.

4) Для резервних ребер - якщо пов'язаний вузол є аварійним, то обчислюємо розрахункову вагу, якщо пов'язаний вузол має розрахункову вагу менше, ніж розрахункова вага поточного вузла з додаванням ваги зв'язуючого ребра, то для пов'язаного вузла встановлюємо рівним розрахунковій вазі поточного вузла з додаванням ваги зв'язуючого ребра.

5) Наступним кроком, алгоритм повинен пройти по всім аварійним вузлам і знайти мінімальне значення розрахункової ваги (мінімального маршруту). Це і буде рішенням пошуку найкоротшого шляху.

6) Для визначення, які ребра потрібно включити, слід пройтися від вузла, знайденого в пункті 5, до активного.

Приклад результату роботи даного алгоритму представлено на рисунку 2. Можна бачити, що при виникненні аварійної ситуації (ребро 1-3) система виконала перерозподіл навантаження і, в даному випадку, ребро 3-4 перейшло зі стану резервного у стан працюючого до часу ліквідації аварії. 
«Системні технологіï» 2 (133) 2021 «System technologies»

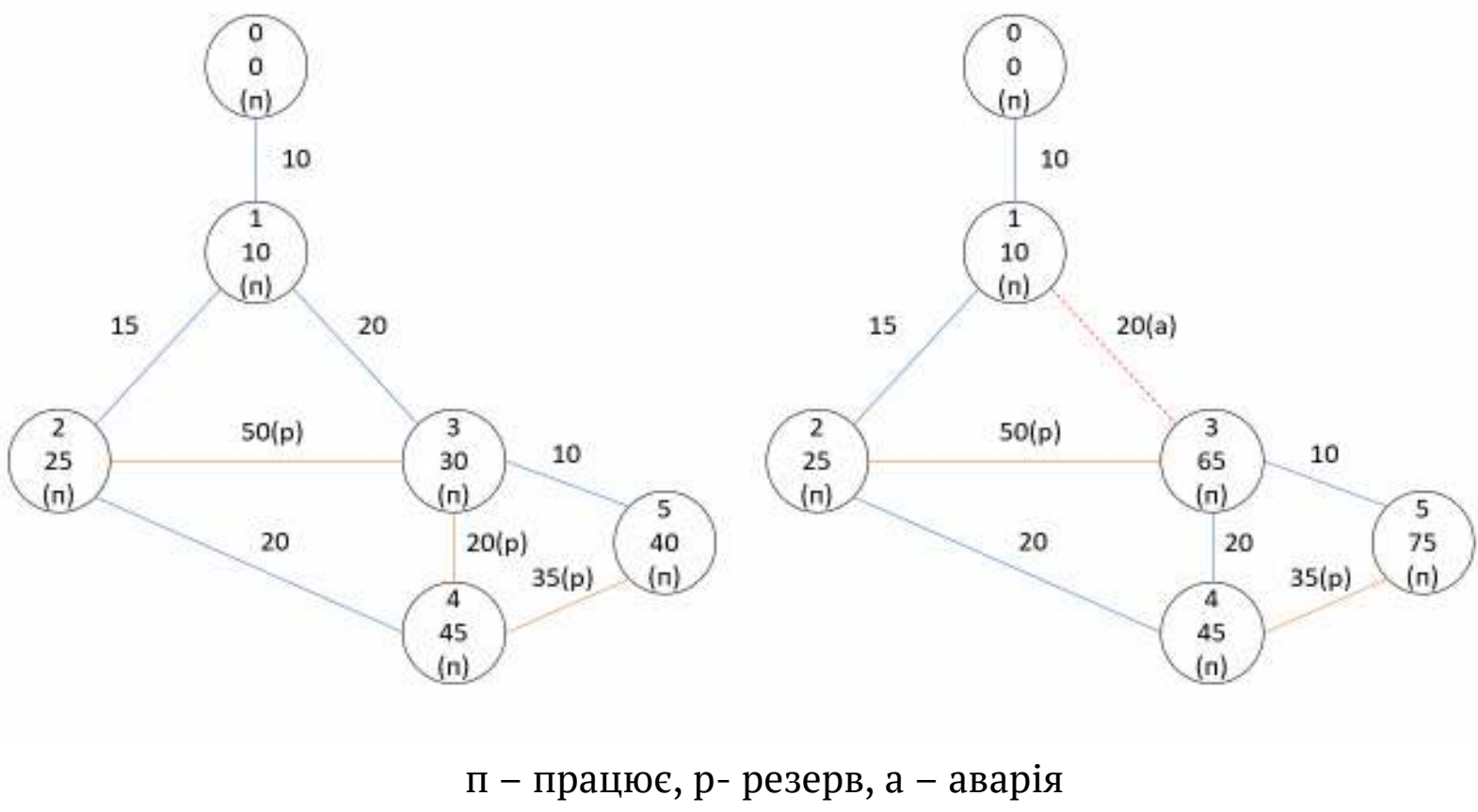

Рисунок 2 - Робота модифікованого алгоритму

Висновки. Вибір алгоритму для досягнення поставленої мети є ключовим. Від правильно обраного алгоритму залежить швидкість роботи програми, правильність обраного маршруту, швидкість ремонтно-відновлювальних робіт. Модифікований алгоритм показав більшу ефективність в порівнянні з іншими алгоритмами, що розглядались, тому на базі його в подальшому реалізовано прототип експертної системи.

\section{ЛІТЕРАТУРА / ЛИТЕРАТУРА}

1. Кацадзе Т.П. Експертні системи прийняття рішень в енергетиці: навч. посіб. / Т.Л. Кацадзе. - К.: ЛОГОС, 2014. - 173 с.

2. Орнов В.Г. Задачи оперативного и автоматизированного управления энергосистемами. / В.Г. Орнов, М. А. Рабинович. - М.:Энергоатомиздат, 1988. - 224 с. 3. Dijkstra's shortest path algorithm [Електронний ресурс]. - Режим доступу: https://www.geeksforgeeks.org/dijkstras-shortest-path-algorithm-greedy-algo-7/

\section{REFERENCES}

1. Katsadze T.P. Ekspertni systemy pryiniattia rishen v enerhetytsi: navch. posib. / T.L. Katsadze. - K.: LOHOS, 2014. - 173 s.

2. Ornov V.G. Zadachi operativnogo i avtomatizirovannogo upravleniya e`nergosistemami. / V.G. Ornov, M. A. Rabinovich. - M.:E`nergoatomizdat, 1988. $224 \mathrm{~s}$. 


\section{«Системні технологіï» 2 (133) 2021 «System technologies»}

3. Dijkstras shortest path algorithm [Elektronnyi resurs]. - Rezhym dostupu: https://www.geeksforgeeks.org/dijkstras-shortest-path-algorithm-greedy-algo-7/

Received 22.02.2021. Accepted 25.02.2021.

\section{Разработка алгоритма для построения прототипа экспертной системы}

\section{диагностики аварийных ситуаций сети}

Используя экспертную систему, можно уменьшить количество информации, которое нужно учитывать диспетчеру и ускорить прочесс принятия решения. Также правильно построенная экспертная система позволит уменьшить количество потенциальных ошибок в принятых решениях. В рамках данной работы было разработано модифицированной алгоритм Дейкстри. Модифицированный алгоритм показал большую эффективность по сравнению с другими алгоритмами, которые рассматривались, потому на базе его в дальнейшем реализован прототип экспертной системы.

\section{Development of an algorithm for construction of a prototype of expert system of diagnostics of network emergencies}

Modern electric power systems belong to the class of large human-machine systems of the cybernetic type that is why development of consulting model of diagnostics of emergency situations is actual. In the conditions of operative management it is related the modes of grids to hard limitation of time for a decision-making, and during prognostication of the perspective modes and planning of development of grids - with a vagueness and ambiguousness of initial information, for example, of data about the perspective loading of grid. Using a consulting model, it is possible to decrease information content it needs to take into account that to the controller and accelerate a decision-making process. Also the correctly built consulting model will allow to decrease the amount of potential errors in made decision.

The up-diffused electric network after the structure reminds count. An example of a task that needs to be decoupled using an automated system would be the selection of a route for reconnecting the power grid to resume the system. In our view, more effective for this task there will be the use algorithm of round of count. Dijkstree's algorithm is a solution to a problem in general form, which will not always be relevant for a particular case. As part of this work, a modified Dijkstree algorithm was developed.

The aim of modification consists in the increase of efficiency of an offer solution, possibility of work in the self-weighted count and exception of errors during the search of alternative way. This result is achieved by memorizing all the connecting nodes and calculating the minimum routes to all vertices, taking into account the lines that are in a state of failure.

Findings. The choice of an algorithm to achieve this goal is key. The speed of the program, the correctness of the chosen route, the speed of repair and renovation work depends on the correctly selected algorithm. The modified algorithm showed large efficiency as compared to other algorithms that was examined, that is why the prototype of consulting model is realized in future on the base of him. 
Глоба Назар Іванович - магістр кафедри Інформаційних технологій i систем, Національна металургійна академія України.

Дмитрієва Ірина Сергіївна - к.т.н., доц., доцент кафедри Інформаційних технологій і систем, Національна металургійна академія України.

Глоба Назар Иванович - магистр кафедры Информационных технологий и систем, Национальная металлургическая академия Украины.

Дмитриева Ирина Сергеевна - к.т.н., доц., доцент кафедры Информационных технологий и систем, Национальная металлургическая академия Украины.

Globa Nazar - Master of the Department of Information Technologies and Systems, National Metallurgical Academy of Ukraine

Dmytriieva Iryna - Ph.D., Associate Professor, Associate Professor of the Department of Information Technologies and Systems, National Metallurgical Academy of Ukraine. 